\title{
DISEASE EPIDEMIOLOGY AND GENETIC DIVERSITY OF Fusarium oxysporum f. sp. elaeidis, CAUSE OF Fusarium WILT OF OIL PALM (Elaeis guineensis Jacq.)
}

\author{
M HEFNI RUSLI*; ALAN E WHEALS**; SWETA SHARMA**; IDRIS A SEMAN* and \\ RICHARD M COOPER ${ }^{\star *}$
}

\begin{abstract}
Vascular wilt disease caused by Fusarium oxysporum $f$. sp. elaeidis (Foe) has devasted oil palm in west and central Africa. This study investigates the spatial distribution of Foe, whereby non-random, clustered patterns of the disease were recorded in four separate plantations in Ghana; infection from tree to tree via elongating roots therefore plays a more significant role than aerial distribution by conidiospores, with management implications. Control of Foe with disease-resistant palm lines can depend on the genetic variability of Foe isolates. Twenty-two putative Foe isolates from several African countries, including Ghana, were obtained from oil palms in infected areas for phylogenetic analysis along with 19 fungal outgroups, using the TEF-1 $\alpha$ gene. The data showed Foe isolates have a monophyletic origin, and therefore limited diversity. Palm adapted isolates of F. oxysporum appear to have evolved independently, as ff. spp. elaeidis, albedinis and canariensis were nested into three independent groups. Slowly developing (chronic) and fast, severe (acute) Fusarium wilt are both evident in plantations and we provide preliminary evidence that Foe isolates' different aggressiveness might contribute to this variation. Sampling for Foe infection from xylem in extracted stem cores revealed the deficiency of field surveys based only on visual symptoms.
\end{abstract}

\section{Keywords: Fusarium oxysporum f. sp. elaeidis, oil palm.}

Date received: 5 June 2017; Sent for revision: 6 June 2017; Received in final form: 9 August 2017; Accepted: 11 August 2017.

\section{INTRODUCTION}

Fusarium vascular wilt is the most important disease of oil palm, endemic in western and central Africa including the Ivory Coast, Ghana, Benin, Nigeria, Cameroon and Congo Democratic Republic (Turner, 1981; Corley and Tinker, 2003). The causal agent is the soil-borne, pathogenic fungus Fusarium

Malaysian Palm Oil Board,

6 Persiaran Institusi, Bandar Baru Bangi,

43000 Kajang, Selangor, Malaysia.

E-mail: mohd.hefni@mpob.gov.my

** Department of Biology and Biochemistry, University of Bath, Bath BA27AY, United Kingdom. oxysporum f. sp. elaeidis (Foe) that invades intact or wounded roots (Cooper, 2011; Cooper and Rusli, 2014). Elongating roots are thought to contact dead or infected roots or debris containing longlived chlamydospores of Foe, which germinate in response to root exudates (Cooper and Rusli, 2014; Flood, 2006). Systemic colonisation then occurs via xylem vessels (Cooper, 2011). Fusarium oxysporum strains are classified based on their host specificity into formae speciales (ff. spp.) of which there are more than 150 (Baayen et al., 2000).

Diseased palms have been found frequently in pairs, indicating spread of the pathogen between neighbouring palms (Prendergast, 1957). This model of tree to tree spread was supported by a 
later report of infected palms in pairs or groups and the greater infection of palms with missing neighbours than those without (Dumortier et al., 1992). Although it is generally accepted that vascular wilt is spread this way, F. oxysporum can also sporulate on male inflorescences. Significant numbers of $F$. oxysporum conidia were trapped from plantation air with four of these isolates pathogenic to seedlings, suggesting the possibility of aerial transmission (Cooper et al., 1989). Aerial dispersal plays a role in Fusarium wilt of some other plant species, including date palm (Cooper et al., 1989; Cooper, 2011). This study, based on four plantations in Ghana, makes the first attempt to undertake a statistical analysis of disease spread.

Two syndromes are seen in adult field palms, 'acute wilt' in which leaves dehydrate and die while retaining their original erect positions until broken off by wind action, follows rapid disease progression; affected palms die within three months. With 'chronic wilt' the disease can develop for many months and even years, but palms become progressively stunted associated with desiccation of older leaves and fracturing of the rachis near the base. The crown can also reduce in diameter and eventually collapse (Corley and Tinker, 2003; Cooper and Rusli, 2014). These differences might reflect local conditions, pathogen inoculum level, and variation between seedling palms or pathogen isolates' aggressiveness. The latter possibility is considered in this study.

Various cultural practices such as planting new palms at distance from old stumps have been attempted (Corley and Tinker, 2003). However, the only sustainable means of controlling Fusarium wilt is through selection and introduction of disease resistant genotypes (Cooper, 2011; Cooper and Rusli, 2014). Stability of resistance depends on the genetic controls of host resistance and pathogen virulence. Single resistance genes have provided long-term protection to relatively slowmoving, soil-borne F. oxysporum, such as hostadapted forms to brassicas and tomato (Lievens et al., 2008; Andolfo et al., 2014). Nevertheless, virulent pathogen races have evolved (Michielse and Rep, 2009). Fusarium resistance in oil palm is claimed to be based on many resistance genes (Meunier et al., 1979), but others have implicated only few genes (de Franqueville and de Greef, 1988; Renard et al., 1993). If resistance to Foe is polygenic, it would increase the chance of resistance remaining durable, especially if Foe spreads locally and clonally and has limited genetic diversity. Currently little is known about the genetic variability of Foe isolates.

Three separate vegetative compatibility groups (VCG) were associated separately with Foe populations in Ghana, Zaire (now known as the Democratic Republic of the Congo) and Ivory Coast/Benin (Dossa et al., 1991). Others claimed groups generally corresponded to geographic origin (such as Zaire, Benin, Ivory Coast) based on restriction fragment length polymorphism (RFLP) using one random DNA probe (Mouyna et al., 1996). We showed, based on RFLP and VCG, isolates were similar within Zaire and Brazil but distinct between them (Flood et al., 1992); however it should be noted that the Brazil isolates originated from West Africa (probably Ivory Coast) (Flood et al., 1992; Mouyna et al., 1996). Therefore based on these early methods, some diversity of Foe populations is apparent.

It was long considered that host plantspecialised forms of $F$. oxysporum would be monophyletic and isolates that shared a host all derived from a single pathogenic genotype (Gordon and Martyn, 1997). However, many ff. spp. are polyphyletic (Laurence et al., 2015). For example f. sp. cubense (banana) and F. oxysporum f. sp. lycopersici (tomato) are scattered over several clades of the species complex ( $\mathrm{O}^{\prime}$ Donnell et al., 1998; Kawabe et al., 2005; Fourie et al., 2009). Characterisation of the phylogeny of $\mathrm{f}$. sp. cubense isolates by compiling sequence data from two ubiquitous genes throughout F. oxysporum (small subunit of mitochondrial DNA mtSSU and TEF-1 $\alpha$ ) revealed five different lineages ( $\mathrm{O}^{\prime}$ Donnell et al., 1998). It appears that pathogenicity and virulence mechanisms involved in specificity have evolved multiple times, possibly through mutation or transposition or spread to distantly related strains through horizontal gene transfer (Baayen et al., 2001) or horizontal chromosome transfer (Ma et al., 2010). Horizontal gene transfer is common in the F. oxysporum species complex and has recently been suggested as the most likely explanation for nonmonophyly of most ff. spp. (Laurence et al., 2015).

Previous studies showed that nuclear large subunit (LSU) and/or ITS rDNA sequence data failed to differentiate several species complexes within Fusarium (O'Donnell et al., 2007). RNA polymerase II subunit (RPB2) nucleotide sequences gave poor bootstrap support for several Fusarium species complexes, even though the sequence was easily aligned across the entire genus. Genes for protein virulence effectors ('SIX' named from proteins secreted in $x y l e m)$ can contribute to host specificity but do not reveal polyphyly (Laurence et al., 2015). The translation elongation factor TEF-1 $\alpha$ gene is a highly informative locus at the species level in Fusarium (Laurence et al., 2015) and non-orthologous copies of the gene have not been detected in the genus. Universal primers of TEF-1 $\alpha$ have been designed that work across the phylogenetic breadth of the genus (Geiser et al., 2004). Therefore this approach was used here in order to study the phylogenetic diversity of the Foe isolates from different backgrounds. 
Understanding of pathogen variability and the nature of disease spread is part of our on-going programme to design sustainable and effective disease control.

\section{MATERIALS AND METHODS}

\section{Sampling Palm Stems with Increment Borers}

Tree increment borers $(400 \mathrm{~mm}$ length; Mattesson, Sweden) were used to remove cores (Mepsted et al., 1991; Cooper, 2011) (5.5 cm diameter) from trunks of diseased and apparently healthy palms in Ghana. Cores were taken perpendicular to the longitudinal stem axis. Brown, discoloured xylem vessels were noted (indicative of Foe infection) and distinction was made between these and natural browning of fibres (Cooper, 2011). Isolation of Foe was from fragments of stem cores (2.5 cm length), which were surface sterilised in $2 \%$ $(\mathrm{v} / \mathrm{v})$ sodium hypochlorite for $5 \mathrm{~min}$ before rinsing twice in sterile distilled water (SDW). The materials were then plated onto a Fusarium-selective medium (FSM) (Papavizas, 1967) and incubated for four days at $28^{\circ} \mathrm{C}$.

Locations of Plantations, Palm Genotypes and Sampling

Data for disease epidemiological and phylogenetic studies were obtained from four locations in three separated oil palm plantations in Ghana: Benso Oil Palm Plantation (BOPP) based at the Adum Banso Estate in Takoradi (001 $54^{\prime} 821^{\prime \prime} \mathrm{N}$ 0506 $\left.643^{\prime \prime} \mathrm{W}\right)$, NORPALM Ghana Limited Plantation (NPM) (503'58.3"N 1 $\left.{ }^{\circ} 53^{\prime} 50.7^{\prime \prime} \mathrm{W}\right)$ also in Takoradi; and Ghana Oil Palm Development Company (GOPDC) in Kade, the eastern region $\left(06^{\circ} 15^{\prime} 22^{\prime \prime} \mathrm{N} 00^{\circ} 56^{\prime} 38^{\prime \prime} \mathrm{W}\right)$. Disease symptom types observed in all fields included palms with chronic and acute symptoms. Three hundred sixty oil palms [Dura x Pisifera progeny (DxP), planted in 1981] including diseased (34 palms) and apparently healthy palms (326 palms) were visually assessed in BOPP plantation for disease. Tissues from diseased (10 palms) and healthy-looking palms (five palms) representative of the affected area were sampled by removing cylinders from trunks with an increment borer from BOPP Plantation and similarly, 15 palms were sampled from NPM Plantation. In NPM Plantation, 520 palms (40 diseased; 480 apparently healthy) were visually recorded. NPM Plantation records showed that the first disease symptoms appeared in 2004 after planting in 1994 with DxP progeny. In GOPDC Plantations (GOPDC1, GOPDC2: different areas of the same plantation) comprising DxP planted in 1979, 20 random stem core samples from palms with symptoms were collected and 317 palms were visually recorded in affected areas. All core samples were isolated onto FSM (Flood et al., 1989).

\section{Fungal Isolates and Growth}

Twenty-five isolates of Foe, other F. oxysporum ff. spp. and other Fusarium spp. were obtained from the University of Bath Culture Collection, CABI, United Kingdom, Agricultural Research Services, USDA, and nine were isolated from Ghanaian Plantations by the authors (Table 1).

Test of Randomness to Establish the Nature of Spread of Fusarium wilt

The disease spatial distribution was analysed using a statistical test. This test supposes that $N$ infected palms are observed within the affected area $S$ and perimeter length $P$, and considers the 'null hypothesis' that the infected palms are 'randomly' (i.e., independently and uniformly) distributed over the affected area (Marcus et al., 1984).

Let $\mathrm{d} 1 . . ., \mathrm{dN}$ denote the distances from each infected palms to its nearest (infected) neighbour. Previous report suggested a test of randomness based on the average nearest-neighbour distance $\mathrm{d}=(\mathrm{d} 1+\ldots+\mathrm{dN}) / \mathrm{N}$. Their test statistic is $\mathrm{CE}=[\mathrm{d}$ - E (d)] / $\sqrt{ }$ var (d) where E(d) is the expectation of $\mathrm{d}$ and var(d) is the variance of d (Clark and Evans, 1954). Note that the observed distances are not independent and may include pairs of identical measurements between some nearest-neighbour pairs. Thus, the following approximations for the expectation and variance of d:

$$
\begin{aligned}
& \mathrm{E}(\mathrm{d})=0.5(\mathrm{~S} / \mathrm{N})^{1 / 2}+\left(0.514+0.412 / \mathrm{N}^{1 / 2}\right) \mathrm{P} / \mathrm{N} \\
& \sqrt{\operatorname{var}(\mathrm{d})}=0.07 \mathrm{~S} / \mathrm{N} 2+0.037 \mathrm{PS}^{1 / 2} / \mathrm{N}^{5 / 2}
\end{aligned}
$$

Using these values, CE follows an approximately standard normal distribution (Ripley, 1979). The null hypothesis of randomness is rejected in favour of non-randomness at level of significance if $\mathrm{CE}$ $<Z \alpha$, where $Z \alpha$ is the lower $\alpha$-quartile of the standard normal distribution.

Polymerase Chain Reaction (PCR) Amplifications of Translation Elongation Factor 1 Alpha (TEF- 1 $\alpha$ ) Gene

PCR reactions were conducted using a PTC$100^{\mathrm{TM}}$ (MJ Research). A standard PCR protocol was used to amplify the TEF- $1 \alpha$ gene region. Forward primer ef1 (5' - ATGGGTAAGGAR (A/G) GACAAGAC - 3') and reverse primer ef2 (5' GGAR(A/G)GTACCAGTS(G/C)ATCATGTT-3') based on (O'Donnell et al., 1998) were used. The annealing temperature was $53^{\circ} \mathrm{C}$. The PCR programme was $90 \mathrm{~s}$ at $94^{\circ} \mathrm{C}$, followed by 40 cycles of $30 \mathrm{~s}$ at $94^{\circ} \mathrm{C}, 90 \mathrm{~s}$ at $55^{\circ} \mathrm{C}$, and $2 \mathrm{~min}$ at $68^{\circ} \mathrm{C}$, 
TABLE 1. FORMAE SPECIALES OF Fusarium oxysporum AND OUT-GROUPS. ISOLATES OBTAINED FROM GHANAIAN OIL PALM PLANTATIONS WERE SAMPLED FROM CHRONIC (C), ACUTE (A) AND SYMPTOMLESS PALMS (H)

\begin{tabular}{|c|c|c|c|c|}
\hline $\begin{array}{l}\text { F. oxysporum } \\
\text { f. sp. }\end{array}$ & Code & Culture collection & Source of origin & Country of origin \\
\hline elaeidis & F1 SS1 & University of Bath & ex. oil palm, Binga nursery. J. Flood. & Republic Congo (DRC) \\
\hline elaeidis & F2 ORI & & ex. oil palm, Binga field microplot. J. Flood. & Republic Congo (DRC) \\
\hline elaeidis & F2 SS2 & & ex. oil palm, Binga field microplot. J. Flood & Republic Congo (DRC) \\
\hline elaeidis & F1 & & ex. oil palm, Binga nursery. J. Flood & Republic Congo (DRC) \\
\hline elaeidis & Y1 ORI & & ex. oil palm. Yaligimba. H. Corley. & Republic Congo (DRC) \\
\hline elaeidis & F3 & & ex. oil palm, Binga nursery. J. Flood & Republic Congo (DRC) \\
\hline elaeidis & $16 \mathrm{~F}$ & & ex. oil palm. IRHO screening isolate & Ivory Coast \\
\hline elaeidis & Y1 SS1 & & ex. diseased oil palm, Yaligimba. & Republic Congo (DRC) \\
\hline elaeidis & OPC1 & & ex. oil palm. Infected root. & Nigeria \\
\hline elaeidis & BRAZIL & CABI & ex. oil palm & Brazil \\
\hline elaeidis & GHANA & & ex. oil palm & Ghana \\
\hline elaeidis & NRRL 36359 & USDA & ex. oil palm, K O’Donnell & Republic Congo (DRC) \\
\hline elaeidis & ВОРР $11 \mathrm{H}$ & Isolates from Ghana & $\begin{array}{l}\text { BENSO Oil Palm Plantation, Ghana, } \\
\text { from symptomless palm. }\end{array}$ & Ghana \\
\hline elaeidis & BOPP 12A & & $\begin{array}{l}\text { BENSO, from palm with 'acute' } \\
\text { Fusarium wilt. }\end{array}$ & Ghana \\
\hline elaeidis & BOPP IC & & BENSO, from palm with 'chronic' wilt & Ghana \\
\hline elaeidis & GOPDC 18C & & $\begin{array}{l}\text { Ghana Oil Palm Development Centre } \\
\text { (GOPDC), from palm with 'chronic' wilt }\end{array}$ & Ghana \\
\hline elaeidis & GOPDC 2C & & GOPDC, from palm with 'chronic' wilt. & Ghana \\
\hline elaeidis & GOPDC $42 \mathrm{H}$ & & GOPDC, from symptomless palm. & Ghana \\
\hline elaeidis & NPM 3C & & $\begin{array}{l}\text { NORPALM Plantation, Ghana, from } \\
\text { palm with 'chronic' wilt. }\end{array}$ & Ghana \\
\hline elaeidis & $\begin{array}{l}\text { NPM } 4 \mathrm{~A} \\
\text { NPM } 1 \mathrm{H}\end{array}$ & & $\begin{array}{l}\text { NORPALM, from palm with 'acute' wilt. } \\
\text { NORPALM, from symptomless palm. }\end{array}$ & $\begin{array}{l}\text { Ghana } \\
\text { Ghana }\end{array}$ \\
\hline \multicolumn{5}{|l|}{$\begin{array}{l}\text { F. oxysporum } \mathrm{ff} . \\
\text { spp.: }\end{array}$} \\
\hline pisi & 1307 & & ex. pea, UK. University of Bath. R. M Cooper. & United Kingdom \\
\hline lycopersici & $32 \mathrm{~A}$ & & ex. tomato, UK. University of Bath. R. M Cooper. & United Kingdom \\
\hline canariensis & 87-Guil2 & & Tenerife, Canary Islands. D. Fernandez. & Canary Islands \\
\hline canariensis & 95-2269 J4G6 & & Palm Beach Co., Florida, USA. G. Simone. & United States \\
\hline
\end{tabular}

followed in turn by one cycle of $5 \mathrm{~min}$ at $94^{\circ} \mathrm{C}$ and $14^{\circ} \mathrm{C}$ holding temperature ( $\mathrm{O}^{\prime}$ Donnell et al., 2007).

\section{Nucleotide Sequence Accession Numbers}

The sequences obtained from 25 isolates of Fusarium oxysporum ff. spp. were deposited in the GenBank database under accession ID5399896 (TEF-1 $\alpha$ ). Fifteen TEF-1 $\alpha$ sequences datasets that had previously been deposited in GenBank (http: / / www.ncbi.nlm.nih.gov) and Fusarium ID (http:/ / www.fusariumdb.org) were used for other Fusarium isolates listed in Table 2.

\section{Sequencing of DNA and Data Analysis}

Sequencing reactions were performed by Fisher Scientific or MyGATC. BLAST searches were performed using the GenBank sequence database to confirm the identity of the sequenced fungal isolates. The output from BLAST algorithms was used to query any unknown sequences against the database of all the fungi in the gene TEF-1 $\alpha$. MEGA5 software (Tamura et al., 2007) was used to edit and align the nucleotide data, after which the alignments were improved manually.

Phylogenetic analyses were conducted with MEGA5 on the data set of TEF- $1 \alpha$ sequences of all 41 isolates included in the present study. Unweighted parsimony analyses were performed with the heuristic search option and 1000 random addition sequences with the MULPARS function on and with tree bisection reconnection branch swapping. The out-group species, F. foetens, selected for rooting the gene trees represents the closest species to Foe. Clade stability was assessed by 1000 parsimony bootstrap replications and decay indices were calculated with TREEROOT (Tamura et al., 2007).

The evolutionary history was inferred using the Maximum Parsimony method (Eck and Dayhoff, 1966). The percentage of replicate trees in which the associated taxa clustered together in the bootstrap 
TABLE 2. TRANSLATION ELONGATION FACTOR 1 ALPHA (TEF-1 $\alpha$ ) SEQUENCES DEPOSITED IN GENBANK (http://www.ncbi.nlm.nih.gov) AND FUSARIUM ID (http:// isolate.fusariumdb.org/) USED AS REFERENCES FOR THE ISOLATES MENTIONED BELOW

\begin{tabular}{cc}
\hline Forma specialis & Accession number \\
\hline elaeidis & FJ985270.1 \\
dianthi & FJ985281.1 \\
canariensis & FJ985388.1 \\
canariensis & AF008485.1 \\
cubense & AF008456.1 \\
cubense & AF008489.1 \\
albedinis & DQ837688.1 \\
albedinis & DQ837686.1 \\
phaseoli & EF056787 \\
gladeoli & EF056787.1 \\
gladeoli & FJ985302 \\
niveum & FJ985410 \\
melonis & FJ985266 \\
batatas & DQ837678 \\
vasinfectum & KP192925 \\
\hline Fusarium $\mathrm{sp}$. & \\
F. foetens & GU170560.1 \\
\hline
\end{tabular}

test (1000 replicates) was assessed to determine the clade stability. The MP tree was obtained using the Close-Neighbour-Interchange algorithm (Nei and Kumar, 2000) in which the initial trees were obtained with the random addition of sequences (10 replicates). All positions containing gaps and missing data were eliminated from the dataset (Complete Deletion option).

Pathogen Isolates, Growth and Inoculum for Pathogenicity Testing

Nine isolates of Fusarium spp. (GOPDC 2C, GOPDC 18C, GOPDC 42H, BOPP 11H, BOPP 12A, BOPP IC, NPM 4A, NPM 3C and NPM 1H) were obtained from palms in BOPP, NPM and GOPDC plantations. These isolates were chosen in order to confirm their pathogenicity and aggressiveness as they were sampled from chronic $(C)$ and acute (A) palms. Fusarium spp. (identified by TEF-1 $\alpha$ sequencing) were sometimes isolated from xylem of healthy-looking palms $(\mathrm{H})$ and these were also tested for pathogenicity. Foe $16 \mathrm{~F}$ from diseased palms in the Ivory Coast was used as a control because the isolate was previously used by Institut de Recherches pour les Huiles et Oléagineux (IRHO) as their pathogenic isolate for Fusarium wilt disease resistance screening; we have routinely confirmed its pathogenicity (Flood et al., 1993). Isolates were stored at $-80^{\circ} \mathrm{C}$ in $20 \%$ glycerol then cultured on Czapek-Dox agar (CDA) and incubated at $25^{\circ} \mathrm{C}$ for five days.

As described previously (Rusli et al., 2015), for inoculum preparation isolates were sub-cultured into $100 \mathrm{ml} \mathrm{CD}$ liquid medium in $250 \mathrm{ml}$ conical flasks for three days, shaken at $150 \mathrm{rpm}$ and $25^{\circ} \mathrm{C}$ then filtered to remove mycelial fragments and centrifuged at $13000 \mathrm{~g}$ for $10 \mathrm{~min}$. The pelleted conidia were re-suspended in $50 \mathrm{ml}$ sterile distilled water and adjusted to 106 spores $\mathrm{ml}^{-1}$. Ten $\mathrm{ml}$ of conidial suspension was applied with a sterile syringe onto the soil surface around the base of each palm of age three months. The inoculum was then watered with sterile distilled water for two weeks. Non-inoculated plants served as controls. Each progeny was represented by 10 replicates using randomised complete block design (RCBD).

\section{Plant Materials}

Oil palm germinated seeds of a susceptible, commercial progeny DxP (Johor Labis and Yangambi) (Durand-Gasselin et al., 2000) were supplied by the Malaysian Palm Oil Board (MPOB). The palms were transferred into black polyethylene bags $(15.2 \times 125.4 \times 25.4 \mathrm{~cm})$ filled with compost (BHGS Ltd Levingtons F2 + sand, BHGS Ltd, Levingtons $\mathrm{M} 2$, perlite in ratio 1:1:1) and grown in a greenhouse at $25^{\circ} \mathrm{C}$ to $32^{\circ} \mathrm{C}$ at the University of Bath, United Kingdom. Palms were supplied monthly with liquid fertiliser (BHGS Ltd; 1 in 45 dilution, containing $\mathrm{N}, \mathrm{P}, \mathrm{K}$ in the ratio of $8: 3: 3$ and trace elements); otherwise they were watered from below on alternate days (Rusli et al., 2015).

\section{Disease Severity Index}

The percentage chlorotic or necrotic leaf index was rated from 0 to 5, $0=$ no symptoms, $1=$ slight necrosis/chlorosis on 1-2 leaf tips - usually oldest leaves; 2 = necrosis/chlorosis over one-quarter of the leaves and some shortening of the youngest leaves; 3 = severe necrosis / chlorosis over one-half of the leaves. Extensive leaf desiccation and stunting; 4 $=$ severe necrosis/chlorosis over three-quarters of the leaves. Extensive leaf desiccation and stunting; 5 = plant dead, as detailed and imaged in a previous study (Rusli et al., 2015). The disease severity index assessment was carried out one month after inoculation then at monthly intervals.

\section{Colonisation of Oil Palm Tissues}

Re-isolation of inoculated Foe from the plant roots, bulbs (lower stem) and petioles of inoculated and un-inoculated palms was conducted at the end of the experiment in week 40 , as previously described (Rusli et al., 2015). For qualitative re-isolation, $0.5 \mathrm{~cm}$ fragments of plant materials (sections of root, petiole or stem core samples taken with an increment borer, internal diameter $5.5 \mathrm{~cm}$ ) (Mepsted et al., 1994) were surface sterilised in $2 \%(\mathrm{v} / \mathrm{v})$ sodium hypochlorite for $10 \mathrm{~min}$ (5 $\mathrm{min}$ for tissue cores) before rinsing 
twice in SDW. Samples were then plated onto FSM (Flood et al., 1989) and incubated for four days at $28^{\circ} \mathrm{C}$.

For quantitative re-isolation, $1 \mathrm{~g}$ fresh weight of root, bulb or petiole tissue was surface sterilised as described above. The tissue was ground with $1 \mathrm{~cm}^{3}$ of sterile sand and $9 \mathrm{ml}$ of SDW. A 10-fold dilution series was prepared and $0.5 \mathrm{ml}$ of the suspension was spread onto triplicate plates of FSM. After incubation at $28^{\circ} \mathrm{C}$ for four days, colonies of Fusarium were counted and the number of colony forming units (CFU) per $\mathrm{g}$ fresh weight of palm tissue was calculated. The data collected were subjected to analysis of variance (ANOVA). Means were separated using contrast statements at significance level of $\mathrm{P}<0.05$. Comparison between means of treatment was made using Tukey HSD.

\section{RESULTS AND DISCUSSION}

\section{Fusarium wilt Occurrence and Spread within Affected Plantations}

For the BOPP Plantation (Figure 1a), where 360 plants were recorded, 33 palms appeared visibly infected. Based on the data evaluated from equation $\mathrm{CE}=[\mathrm{d}-\mathrm{E}(\mathrm{d})] / \sqrt{\mathrm{v} a r}(\mathrm{~d})$, the hypothesis of randomness is rejected in favour of clustering at a significance level $\mathrm{p}<0.01$ at -10.27 . The same conclusion was reached from the data from NPM Plantation (Figure 1b) where the disease pattern in the plantation was due to cluster distribution $(p<0.01)$. ANOVA performed on the infected palms' distribution in GOPDC 1 Plantation (Figure 1c) also showed the $C E$ value significance at $p<0.01$, which reflects cluster distribution instead of random distribution. The same conclusion was reached for the data of the GOPDC 2 Plantation (Figure 1d). A cluster distribution was evident in the field and once again, the null hypothesis of randomness is rejected in favour of non-randomness at $(p<0.01)$.

\section{Genetic Variation of Foe Isolates between and within Countries}

Phylogenetic trees from parsimony bootstrap analysis of Foe obtained from plantations in Ghana and Foe from six different countries were examined based on the TEF-1 $\alpha$ gene (Figure 2). A total of 22 strains of Fusarium isolated from oil palm xylem were chosen for the study along with 19 other Fusarium strains for comparative purposes. All Foe isolates that were isolated from diseased palms from various countries had previously been positively tested for pathogenicity, except Foe Brazil, Foe F2SS2, Foe NRRL 36359 and Foe 38313 (Mepsted et al., 1991). The Ghanaian isolates were confirmed as Foe by their pathogenicity to oil palm, as part of this study (Figure 3). TEF-1 $\alpha$ sequences obtained from GenBank and Fusarium ID (Table 2) were also included in the analyses.

The constructed phylogenetic tree based on the nucleotide sequence alignment of the 680 bp nucleotides, excluding any uninformative characters showed the monophyletic nature of Foe (Figure 2). The earliest diverging lineage (83\% bootstrap support) comprised 17 strains of Foe representing clade 1; while other Foe isolates BOPP IC, GOPDC 42H, BOPP $11 \mathrm{H}$ and GOPDC $2 \mathrm{C}$ were in clade 2 with $98 \%$ bootstrap support. Strains of Foe appear to be closely related with no correlation to geographical origin. Isolates from different plantations and countries are similar to one another. Formae speciales of F. oxysporum from other palms, f. sp. albedinis and f. sp. canariensis, were nested into three independent groups. Representatives of Foe isolates obtained from Ghana that appeared within the Foe clade were tested for their pathogenicity on oil palm. A single Ghanaian isolate (NPM 1H) that was obtained from a symptomless palm, but fell outside clades 1 and 2, was also subjected to pathogenicity testing in order to compare with the phylogeny results.

\section{Evaluation of Pathogenicity of Ghanaian Isolates from Different Plantations and Based on Chronic, Acute and Symptomless Palms}

Foe isolates from Ghana scattered around the Foe clade were inoculated onto palm seedlings to evaluate pathogenicity and to confirm identity as f. sp. elaeidis. The evaluation of pathogenicity of Foe isolates from chronic and acute palms (six isolates, plus aggressive control isolate $16 \mathrm{~F}$ ) and of F. oxysporum from symptomless palms (three isolates) also was carried out in order to establish any link between the levels of aggressiveness of the isolates and symptom development and intensity.

All Foe isolates tested showed different levels of aggressiveness even though they are from related clades 1 and 2 (Figure 2). BOPP 12A resulted in gradually progressing symptoms throughout and gave the highest mean wilt index after 40 weeks, together with the isolate Foe 16F, of already established high aggressiveness (Flood et al., 1989) (Figure 3). Both isolates induced significantly greater vascular necrosis (browning) compared to other isolates (results not shown). The high level of aggressiveness of the Foe isolate might reflect that it was isolated from a palm with acute symptoms, yet another Foe isolate from an acute symptoms palm (NPM 4A) was much less aggressive, and similar to BOPP IC. Nevertheless, all Foe isolates isolated from chronic palms only showed disease progression at or after 24 weeks, which could explain the slow disease development observed in the field. 
(a)

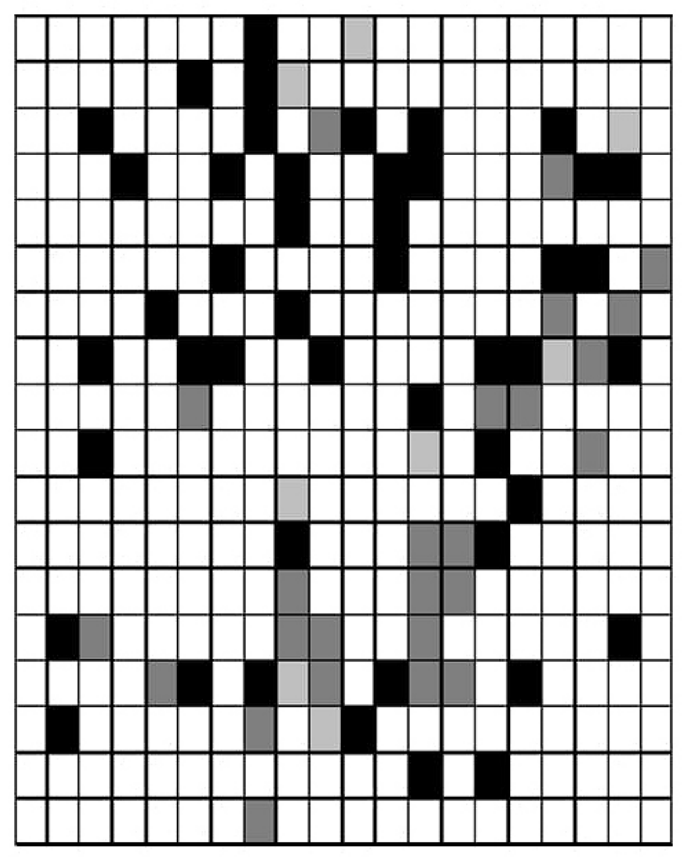

(c)

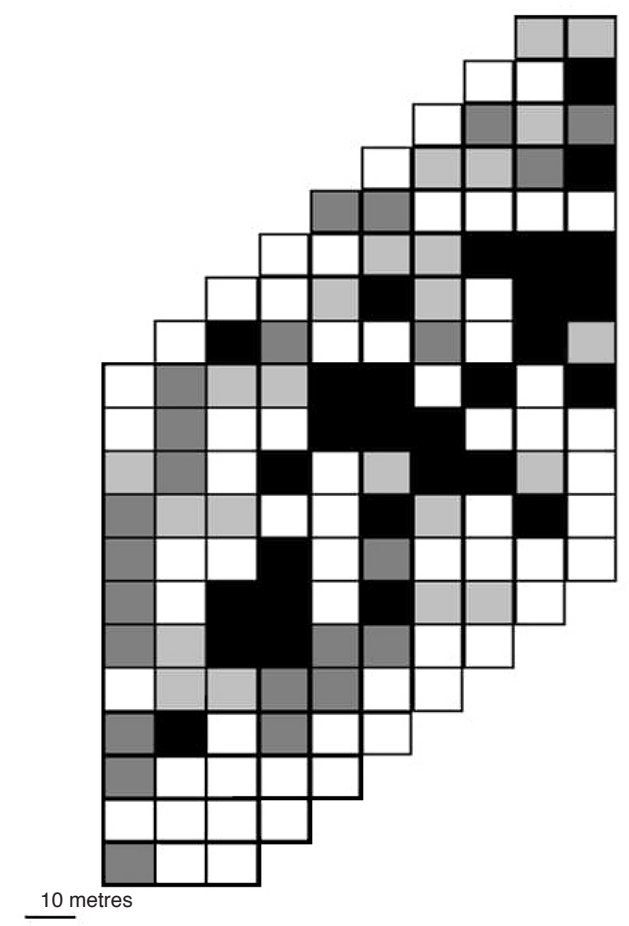

(b)

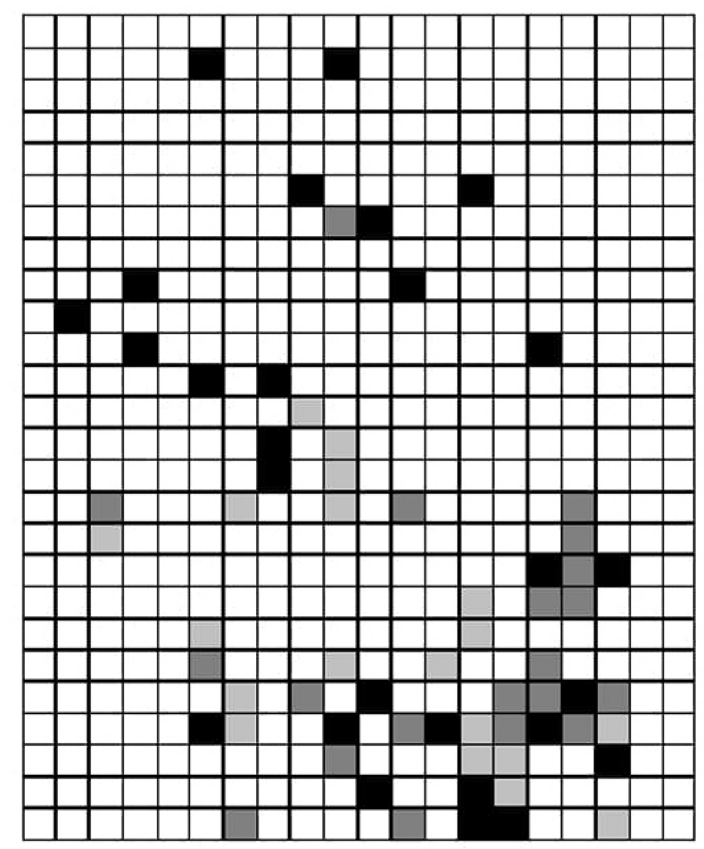

(d)

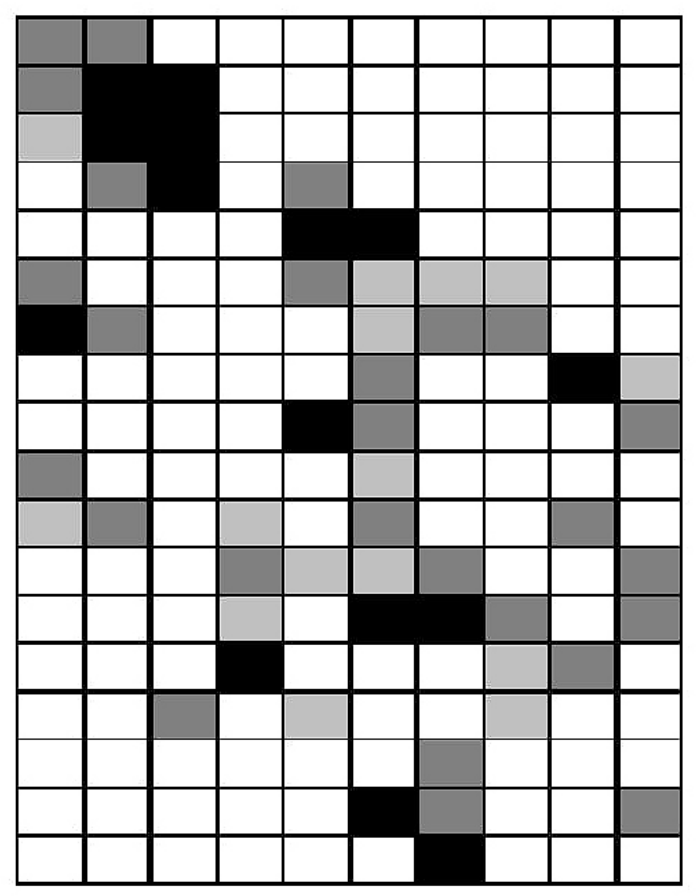

Legend:

\begin{tabular}{|l|l|l|l|}
\hline & Symptomless palm & & Missing palm \\
\hline & Chronic palm & & Acute/dead palm \\
\hline
\end{tabular}

Figure 1. Spatial pattern map of disease severity caused by Foe in: Benso Oil Palm Plantation (BOPP) (a), NORPALM Ghana Limited Plantation (NPM) (b), Ghana Oil Palm Development Company (GOPDC) 1 (c) and GOPDC 2 (d) affected area. These areas represent hot-spots where Foeaffected areas were clearly evident visually. Oil palms were planted at a distance of $10 \mathrm{~m}$ from each other; therefore each square represents one palm at $10 \mathrm{~m}$ distance from adjacent palms. 


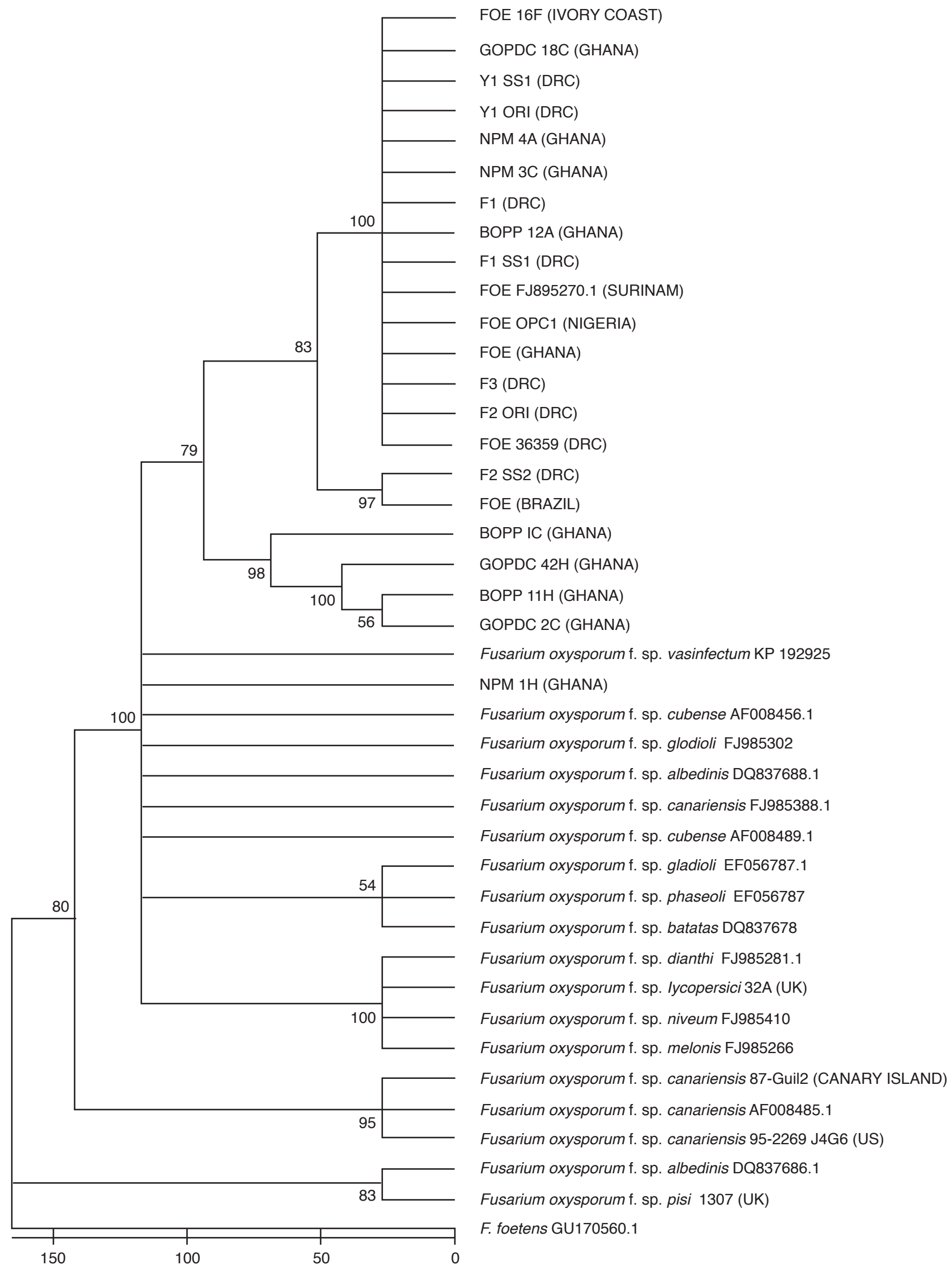

Figure 2. Phylogenetic tree of $\mathrm{F}$. oxysporum $f$. sp. elaeidis inferred from combined (TEF-1 $\alpha$ ) sequence data. The phylogenetic tree was constructed using maximum parsimony analysis with 22 strains of Fusarium and 19 out groups. The tree is rooted with $\mathrm{F}$. foetens. 


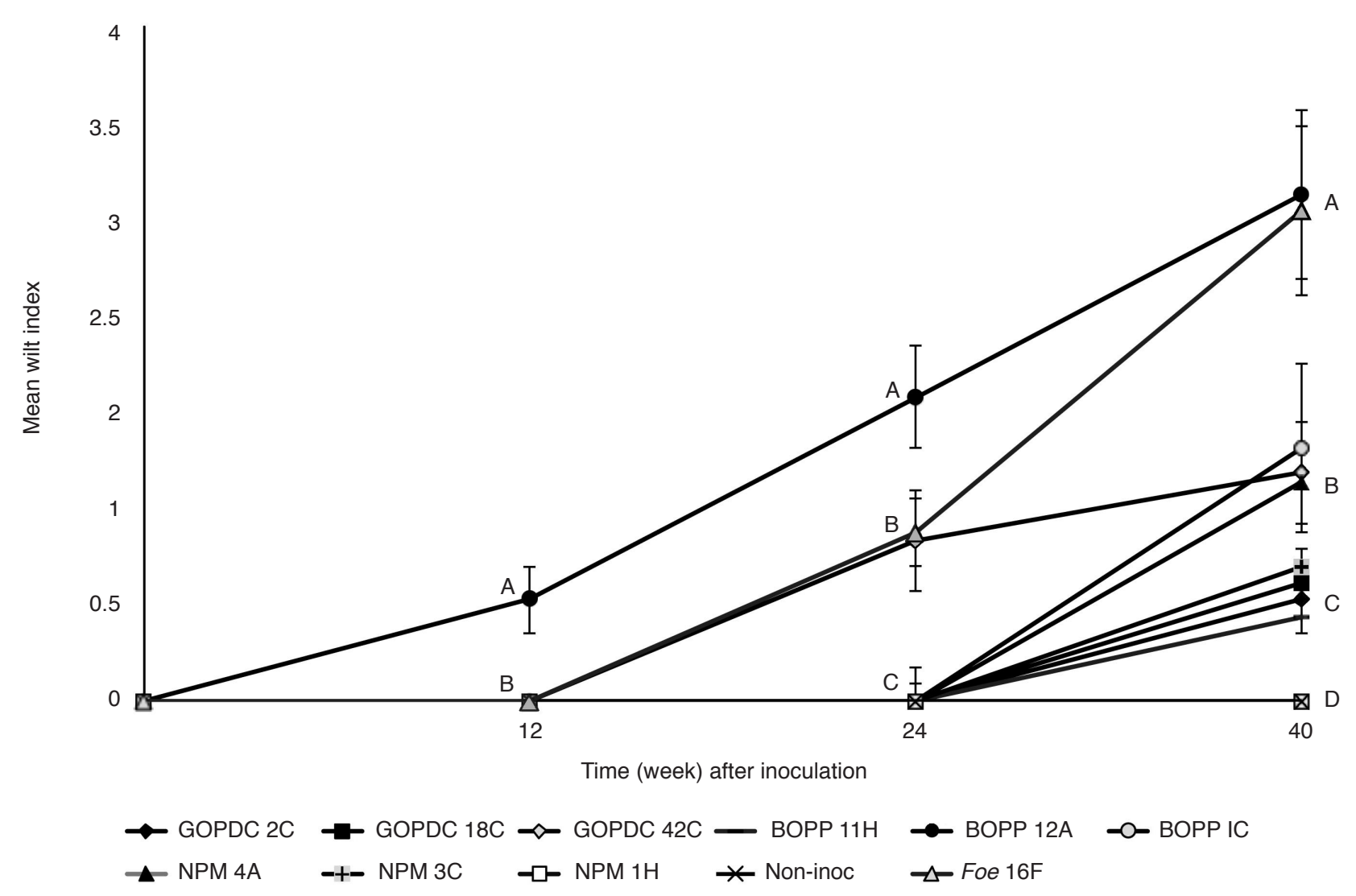

Figure 3. Disease symptoms in oil palms induced by Ghanaian isolates of F. oxysporum. Values represent $n=10$ replicates, with each letter denoting significant differences $(p \leq 0.05)$ between treatments according to week after inoculation; analysed with Tukey (IBM SPSS). Error bars represent standard error (SE) for each treatment. Isolates were from plantations: Ghana Oil Palm Development Company (GOPDC), Benso Oil Palm Plantation (BOPP) or NORPALM Ghana Limited Plantation (NPM), and were from chronic (C), acute (A) or symptomless (H) palms. Isolate $16 \mathrm{~F}$ is included as a control known pathogenic isolate (see Table 1 and methods).

Qualitative re-isolation showed some of the isolates, such as BOPP $12 \mathrm{~A}$ and Foe $16 \mathrm{~F}$ colonised root, bulb, $1^{\text {st }}, 3^{\text {rd }}$ and $7^{\text {th }}$ leaves of the inoculated oil palms, while others were more limited in their extent of colonisation (data not shown). Based on quantitative re-isolation, Foe $16 \mathrm{~F}$ intensively colonised the root tissue and bulb at ca. $10^{4} \mathrm{CFU} \mathrm{g}^{-1}$ fresh weight followed by BOPP $12 \mathrm{~A}$ at $10^{3} \mathrm{CFU} \mathrm{g}$. (Figure 4). These isolates were also present in greater amounts in petioles of the $1^{\text {st }}, 3^{\text {rd }}$ and $7^{\text {th }}$ leaves compared to others. Therefore high colonisation density of BOPP 12A and Foe 16F CFU was linked with rapid and early disease development (Figure 3). Slower and milder disease development by other isolates usually reflected lower colonisation density by these isolates. GOPDC $2 \mathrm{C}$ is a notable exception with equivalent colonisation of root and bulb tissues to BOPP 12A and 16F.

Some isolates from symptomless palms (GOPDC $42 \mathrm{H}$ and BOPP $11 \mathrm{H}$ ) also showed substantial colonisation of all tissues and induced eventual symptoms (Figure 3), whereas GOPDC 18C colonised systemically but palms remained symptomless; NPM 1H induced neither symptoms nor significant colonisation. Other possibly endophytic Fusarium spp., were also recovered from control palms at ca. $10^{1} \mathrm{CFU} \mathrm{g}^{-1}$ in root and bulb tissues but not in petioles.

Presence of Foe and Other Fusarium spp. in Symptomless Palms

Forty-five core samples were taken from trunks of 45 standing oil palms in the GOPDC area where eight of the sampled palms exhibited external Fusarium wilt symptoms. According to re-isolation onto FSM and identification based on isolates' similarity to Foe TEF-1 $\alpha$ sequences in GenBank, 13 (29\%) palms contained Foe, including five palms classed as healthy by external appearance.

Isolates of other Fusarium spp. were occasionally re-isolated from symptomless palms (as above) and revealed by TEF-1 $\alpha$ sequencing as $F$. solani, F. equiset $i$ and F. oxysporum. 


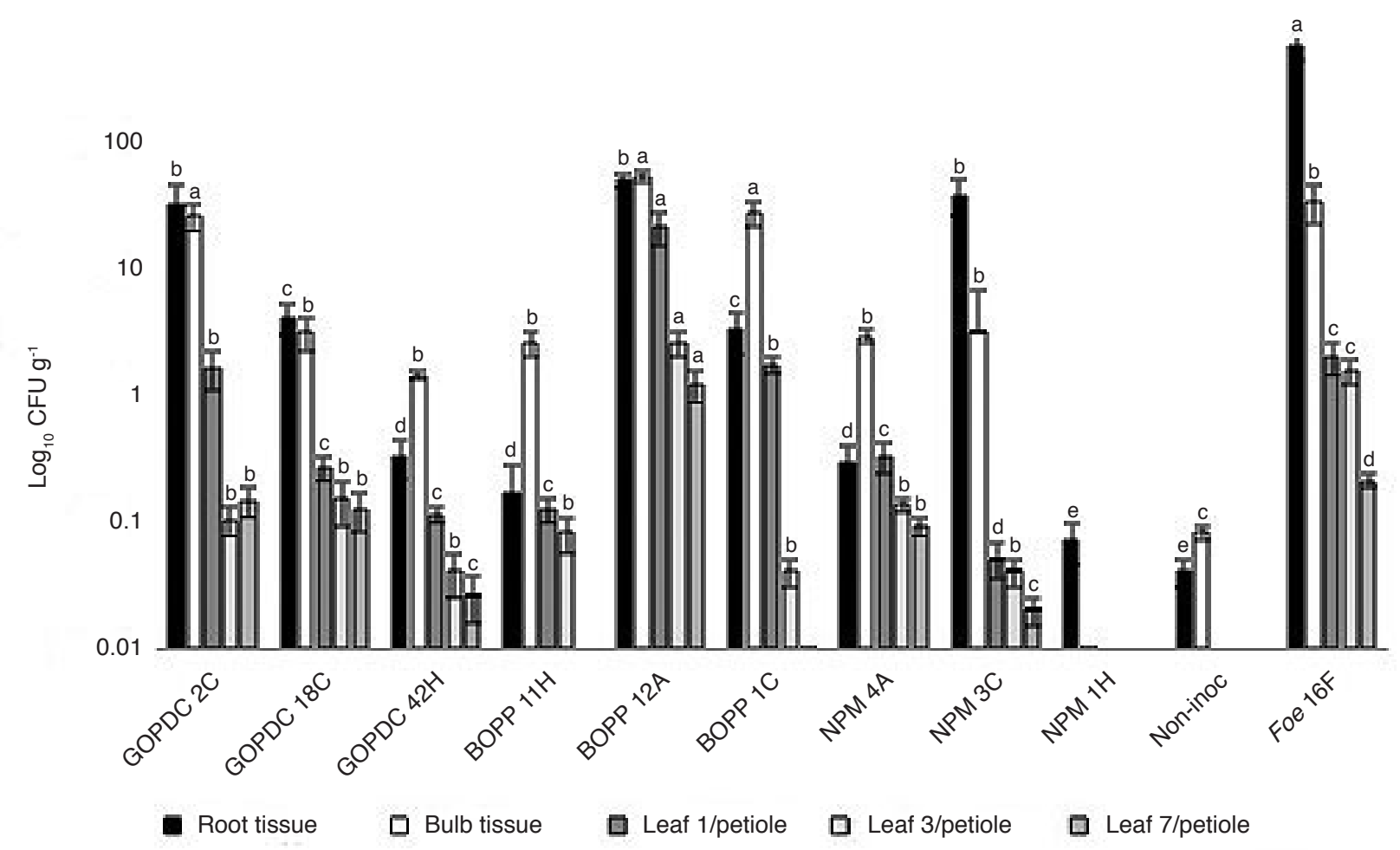

Figure 4. Quantitative re-isolation of Ghanaian isolates 40 weeks post inoculation. Each treatment consisted of 10 replicates of oil palm seedlings. Error bars represent standard error (SE) for each treatment and each letter denotes significant differences ( $p \leq 0.05$ ) between colony forming units (CFU) of each plant part (root, bulb, leaf 1, leaf 3 and leaf 7); analysed with Tukey (IBM SPSS). GOPDC, BOPP, NPM are isolates from Ghanaian plantations from chronic $(C)$, acute $(A)$ or symptomless $(H)$ palms. Non-inoc., non-inoculated control. Isolate $16 F$ is included as a control known pathogenic isolate (see Table 1 and methods).

\section{CONCLUSION}

Spatial distribution analysis of disease incidence indicated non-random patterns of disease were evident in four Ghanaian plantations. These results strongly suggest that palm to palm infection via roots plays the key role in establishment of Foe infection, even though the potential for aerial spread by conidia has been suggested (Cooper et al., 1989). F. oxysporum f. sp. radicis-lycopersici spreads from infected to neighbouring plants via root-toroot dissemination (Rekah et al., 2000) and for coffee wilt caused by Fusarium xylarioides, one infected tree can infect up to three healthy trees in any direction, resulting in an aggregated pattern (Musoli et al., 2008).

Palms killed by Foe become a source of nutrients as well as inoculum for extending roots of adjacent palms, which can then form clusters of diseased and dead palms (Flood, 2006; Cooper, 2011). On a larger scale, in an area where the main cause of palm death was Fusarium wilt, it was reported that of 1600 palms without missing neighbours $17 \%$ had wilt, compared with $24 \%$ infection of 1000 palms with one or more neighbours missing (Dossa et al., 1991). Clearly, information on the role of diseased palms in extent and rate of disease spread is important for designing effective control management strategies. The secondary roots of oil palm can grow as far as 25 m horizontally (Jourdan et al., 2000) thus, eradication of infected palms at the earliest opportunity, before root elongation, should minimise disease spread and inoculum potential.

We detected the presence of Foe in ca. $11 \%$ of symptomless palms in GOPDC Plantation and also occasionally found in the other Ghanaian plantations, palms with apparent Fusarium wilt symptoms that were not infected by Foe (Cooper, 2011). This reveals that visual disease surveys may not show the true picture of the level of infection and we recommend that they are supported by internal inspection with increment borers (Mepsted et al., 1991; Cooper, 2011). Fusarium solani, F. equiseti and F. oxysporum spp. isolates were also found in symptomless palms, as confirmed through molecular identification. These three Fusarium species and F. verticillioides and $F$. incarnatum were identified on contaminated oil palm pollen (Flood et al., 1990) and F. equiseti has been associated with oil palm seedling root rot, spear rot and bud rot (Turner, 1981). We cannot know at this stage if they are pathogens, contaminants or endophytes. On the other hand, F. oxysporum isolates from within palms are more likely to be endophytic, in view of the many forms of this 
species adapted for vascular (xylem) colonisation; systemic but symptomless invasion of oil palms was found for some Malaysian strains of F. oxysporum (Flood et al., 1989). We also isolated F. oxysporum as one of several putative endophytes from within roots and lower stems of uninoculated oil palm seedlings grown in plantation soils from Malaysia under United Kingdom conditions (unpublished data). Notably, the putative endophytic F. oxysporum isolates inhibited to various extents Foe isolates on dual culture plates (unpublished data) so could conceivably influence pathogen colonisation.

Based on the sequence information from TEF-1 $\alpha$, this study demonstrates that Foe has a monophyletic origin. Seventeen Foe isolates from six different countries resolved into one clade comprising two independent lineages with a support value of $83 \%$, suggesting a moderate level of genetic diversification. Four other isolates BOPP IC, GOPDC $42 \mathrm{H}$, BOPP $11 \mathrm{H}$ and GOPDC $2 \mathrm{C}$ also grouped together but are located in clade 2 with a support value of $98 \%$. They possibly evolved from different local ancestral strains, as argued for $\mathrm{f}$. sp. vasinfectum on cotton, which exists as two VCG in Australia (Wang et al., 2006). The low level of diversity in Foe reported here might explain the reported long-term stability of lines bred in Africa for Fusarium wilt resistance (Cochard et al., 2005; Rusli et al., 2015).

However, there is a risk with a potentially variable pathogen such as Foe, that palms selected for resistance in one area might be susceptible to infection elsewhere. In general, this seems unlikely based on findings where inoculation of 14 palm clones with three Foe isolates from different parts of Africa showed variation in aggressiveness, but clone-isolate interactions were not significantly different (Mepsted et al., 1994). Nevertheless, sometimes the ranking of isolates by clones varied considerably, leading to a possible explanation why a few apparently resistant crosses have proved susceptible when planted in areas remote from where their resistance was assessed (Flood et al., 1993; Mepsted et al. 1994). We also recently found differential interactions between some Foe isolates and palm lines (Rusli et al., 2015).

It is tenable that $F$. oxysporum ff. spp. that have adapted to different palm hosts might share similarities because they will have had to overcome related anatomical and biochemical barriers. However, we found Foe, f. sp. albedinis (date palm) and f.sp.canariensis (Canary Islands date palm) were nested into independent lineages. Formae speciales canariensis, f. sp. albedinis, f. sp. palmarum (Syagrus romanzoffiana and Washingtonia robusta hosts in Florida) and Foe have independent evolutionary origins (Phyler et al., 2000). Previous work also shown that f. sp. palmarum is more closely related to f. sp. albedinis than to Foe or to f. sp. canariensis
(Elliot et al., 2010). It appears that evolution of palm pathogenic forms were probably driven by the geographical separation of their host plants. Notably, Australian isolates of f. sp. canariensis are diverse and show an independent evolutionary origin from an extensive international population, which showed little genetic diversity (most isolates belonged to a single VCG and with only four RFLP haplotypes) (Phyler et al., 2000; Gunn and Summerell, 2002; Laurence et al., 2015).

The different forms of Fusarium wilt expression in the field, expressed as chronic or acute, might reflect variation in individual palms, which are not clonal but derive from seed; or they might result from different levels of aggressiveness in Foe isolates; or could reflect the timing of infection and inoculum load of an individual palm. All isolates from both types of syndrome were pathogenic, but varied in aggressiveness. The most aggressive isolate came from an acute infection and as well as inducing extreme symptoms, it was present in highest amounts in palm roots, stems and petioles. Some isolates from chronic infections were also effective colonisers but resulted in later and milder symptoms. Some F. oxysporum isolates (coded ' $\mathrm{H}$ ') from symptomless palms, colonised systemically but showed low or no aggressiveness, as reported previously in Malaysia with soil isolates of F. oxysporum (Flood et al., 1989).

This wide range of responses may well reflect the field situation of this chronic disease, where the presence within a palm of a Foe isolate might be a recent colonisation event or an infection that has been accumulating for months or even years. Even under controlled conditions with inoculated seedlings, disease expression takes several months (Cooper, 2011; Rusli et al., 2015). Greater numbers need to be tested to establish any firm correlation between isolate aggressiveness and chronic or acute wilt, but there was limited availability of palm seedlings in our United Kingdom-based facility to provide sufficient replication in light of palm seedling variation. Future work should ideally involve clonal palms for both natural infection in the field and for pathogenicity testing in the laboratory.

Knowledge of the phylogeny and epidemiology of Foe is important in developing control strategies based on use of resistant genotypes and cultural control measures. This is the first report of either phenomenon for this major disease.

\section{ACKNOWLEDGEMENT}

This research was supported by MPOB with a studentship to the first author. We thank colleagues in MPOB for providing the oil palm seedlings for this study. This work was conducted at the University of 
Bath, United Kingdom under the FERA Plant Health Licence PHL 188A/6475. We gratefully acknowledge the cooperation of plantations in Ghana to allow access, evaluations and sampling: Benso Oil Palm Plantation (BOPP) Takoradi, NORPALM Ghana Limited Plantation (NPM), Takoradi and Ghana Oil Palm Development Company (GOPDC) in Kade. We are indebted to the Oil Palm Research Institute, Kusi, Kade, Ghana for organising these field surveys in particular S Tagoe and K Afrim. We acknowledge K O'Donnell's (USDA) generous provision of many Fusarium isolates. The authors wish to thank the Director-General of MPOB for permission to publish this study.

\section{REFERENCES}

ANDOLFO, G F; FERRIELLO, F; TARDELLA, L; FERRARINI, A; SIGILLO, L; FRUSCIANTE, L and ERCOLANO, M R (2014). Tomato genome-wide transcriptional responses to Fusarium wilt and tomato mosaic virus. PLoS ONE, 9: e94963. http: / / dx.doi.org/10.1371/journal.pone.0094963

BAAYEN, R P; O'DONNELL, K; BONANTS, P J, CIGELNIK, E; KROON, L P; ROEBROECK, E J and WAALWIJK, C (2000). Gene genealogies and aFLP analyses in the Fusarium oxysporum complex identify monophyletic and nonmonophyletic formae speciales causing wilt and rot disease. Phytopathology, 90: 891-900. https: / / doi. org/10.1094/PHYTO.2000.90.8.891

BAAYEN, R P; O’DONNELL, K; BONANTS, P J M; CIGELNIK, E; KROON, L P N M; ROEBROECK, E J A and WAALWIJK, C (2011). Gene genealogies and AFLP analyses in the Fusarium oxysporum complex identify monophyletic and nonmonophyletic formae speciales causing wilt and rot disease. Phytopathology, 90: 891-900. DOI: 10.1094/ PHYTO.2000.90.8.891.

CLARK, P J and EVANS, F C (1954). Distance to nearest neighbour as a measure of spatial pattern in biological populations. Ecology, 35: 445-453. http://links.jstor.org/ sici=0012$9658 \% 28195410 \% 2935 \% 3$ A 453 c $445 \%$ 3ADTNNAA $\% 3 \mathrm{E} 2.0 . \mathrm{CO} \% 3 \mathrm{~B} 2-\mathrm{J}$

COCHARD, B; AMBLARD, $\mathrm{P}$ and DURANDGASSELIN, T (2005). Oil palm genetics and sustainable development. Oleagineux Corps Gras Lipids, 12: 141-147. http:// citeseerx.ist.psu.edu/ viewdoc/download?doi=10.1.1.917.8451\&rep=rep1 \&type $=$ pdf

COOPER, R M; FLOOD, J and MEPSTED, R (1989). Fusarium wilt of oil palm: transmission, isolate variation, resistance. Vascular Wilt Diseases of Plants (Tjamos, E C and Beckman, C H eds.). p. 247-250. NATO ASI Series. Springer-Verlag. DOI: 10.1007 / 978-3-642-73166-2_18.

COOPER, R M (2011). Fusarium wilt of oil palm: a continuing threat to Southeast Asian plantations. The Planter, 87: 409-418. https://www.cabdirect. org/cabdirect/ abstract/ 20113317744

COOPER, R M and RUSLI, M H (2014). Threat from Fusarium wilt disease of oil palm to South-east Asia and suggested control measures. J. Oil Palm Res. Vol. 26: 109-119. http: / /jopr.mpob.gov.my/threat-fromfusarium-wilt-disease-of-oil-palm-to-south-eastasia-and-suggested-control-measures / ?v=true

CORLEY, R H V and TINKER, P B (2003). The Oil Palm. $4^{\text {th }}$ Edition. Blackwell Science Ltd, United Kingdom. http:/ / onlinelibrary.wiley.com/doi/ 10.1002/9780470750971.fmatter/pdf

DE FRANQUEVILLE, $\mathrm{H}$ and DE GREEF, W (1988). Hereditary transmission of resistance to vascular wilt of the oil palm: facts and hypotheses. Proc. of the 1987 International Oil Palm Conference. Progress and Prospects (A Halim Hasan et al., eds.). PORIM, Bangi. p. 118-129.

DOSSA, C; PANDO-BAHUON, A; RENARD, J L and BOISSON, C (1991). Determination of vegetative compatability groups in African Fusarium oxysporum strains isolated from vascular wilt-infected oil palms. Oleagineux, 46: 145-147. http://agritrop. cirad.fr/427856/

DUMORTIER, F; VAN AMSTEL, H and CORLEY, R H V (1992). Oil Palm Breeding at Binga, Zaire. 19701990. Unilever Plantations, London. http:/ / www. cabi.org/isc/ datasheet/ 24639

DURAND-GASSELIN， T; DIABAT, $S$; $\quad$ DE FRANQUEVILLE, H; COCHARD, B and ADON, B (2000). Assessing and utilizing sources of resistance to Fusarium wilt in oil palm (Elaeis guineensis Jacq.). Proc. of the International Symposium on Oil Palm Genetic Resources and their Utilization. p. 446-470. http:/ / agritrop.cirad.fr/525609/

ECK, R V and DAYHOFF, M O (1966). Atlas of Protein Sequence and Structure. National Biomedical Research Foundation, Silver Springs, MD. http:/ / www.worldcat.org/title/ atlas-of-protein-sequenceand-structure-1966/oclc/ 499052378

ELLIOTT, M L; DES JARDIN, E A; O'DONNELL, K; GEISER, D M; HARRISON, N A and BROSCHAT, T K (2010). Fusarium oxysporum $\mathrm{f}$. sp. palmarum, a novel forma specialis causing a lethal disease of Syagrus 
romanzoffiana and Washingtonia robusta in Florida. Plant Dis., 94: 31-38. DOI:10.1094 / PDIS-94-1-0031.

FLOOD, J; COOPER, R M and LEES, P E (1989). An investigation of pathogenicity of four isolates of Fusarium oxysporum from South America, Africa and Malaysia to clonal oil palm. J. Phytopathol., 124: 8088. DOI: 10.1111/j.1439-0434.1989.tb04898.x.

FLOOD, J; MEPSTED, R and COOPER, R M (1990). Potential spread of Fusarium wilt of oil palm on contaminated seed and pollen. Mycol. Res., 94: 708-709. http://agris.fao.org/agris-search/search. do? recordID=MY19940025666

FLOOD, J; WHITEHEAD, D $S$ and COOPER, R M (1992). Vegetative compatibility and DNA polymorphisms in Fusarium oxysporum f. sp. elaeidis and their relationship to isolate virulence and origin. Physiol. Mol. Plant. Pathol., 41: 201-215. DOI: 10.1016/0885-5765 (92)90011-J.

FLOOD, J; MEPSTED, R; VELEZ, A; PAUL, T and COOPER, R M (1993). Comparison of virulence of isolates of Fusarium oxysporum f. sp. elaeidis from Africa and South America. Plant Pathol., 42: 168 171. DOI: $10.1111 /$ j.1365-3059.1993.tb01487.x.

FLOOD, J (2006). A review of Fusarium wilt of oil palm caused by Fusarium oxysporum f. sp. elaeidis. Phytopathology, 96: 660-662. DOI: 10.1094/ PHYTO-96-0660.

FOURIE, G; STEENKAMP, E T; GORDON, T R and VILJOEN, A (2009). Evolutionary relationships among the Fusarium oxysporum f. sp. cubense vegetative compatibility groups. Appl. Environ. Microbiol., 75: 4770-4781. DOI: 10.1128/AEM.0037009.

GEISER, D M; JIMENEZ-GASCO, M; DEL MAR KANG, S; MAKALOWSKA, I; VEERARAGHAVAN, $\mathrm{N}$; WARD, T J; ZANG, N; KULDAU, G A and O'DONNELL, K (2004). FUSARIUM-ID v. 1.0: a DNA sequence database for identifying Fusarium. Eur. J. Plant. Pathol., 110: 473-479. DOI:10.1023/ B:EJPP.0000032386.75915.a0.

GORDON, T R and MARTYN, R D (1997). The evolutionary biology of Fusarium oxysporum. Annu. Rev. Phytopathol., 35: 111-128. DOI: 10.1146/annurev. phyto.35.1.111.

GUNN, L V and SUMMERELL, B A (2002). Differentiation of Fusarium oxysporum isolates from Phoenix canariensis (Canary Island date palm) by vegetative compatibility grouping and molecular analysis. Australas. Plant Pathol., 31: 351-358. DOI:10.1071/ AP02039.
JOURDAN, C; MICHAUX-FERRIERE, $\mathrm{N}$ and PERBAL, G (2000). Root system architecture and gravitropism in the oil palm. Ann. Bot., 85: 861-868. DOI: https: / / doi.org/10.1006/ anbo.2000.1148.

KAWABE, M; KOBAYASHI, Y; OKADA, G; YAMAGUCHI, I; TERAOKA, T and ARIE, T (2005). Three evolutionary lineages of tomato wilt pathogen, Fusarium f.sp. lycopersici, based on sequences of IGS, AT1 and pg1 are each composed of isolates of a single mating type and a single or closely related vegetative compatibility group. J Gen. Plant Pathol., 71: 263-272. DOI:10.1007/s10327-005-0203-6.

LAURENCE, M H; SUMMERELL, B A and LIEW, E C Y (2015). Fusarium oxysporum f. sp. canariensis: evidence for horizontal gene transfer of putative pathogenicity genes. Plant Pathol., 64: 1068-1075. DOI: $10.1111 /$ ppa.12350.

LIEVENS, B; REP, $\mathrm{M}$ and THOMMA, $\mathrm{P} \mathrm{H} \mathrm{J}$ (2008). Recent developments in the molecular discrimination of formae speciales of Fusarium oxysporum. Pest Manag. Sci., 64: 781-788. DOI: 10.1002 / ps.1564.

MA, L J; VAN DER DOES, H C; BORKOVICH, K A; COLEMAN, J; DABOUSSI, M J; DI PIETRO, A; DUFRESNE, M; FREITAG, M; GRABHERR, M; HENRISSAT, B; HOUTERMAN, P M; KANG, S; SHIM, W B; WOLOSHUK, C; XIE, X; XU, J R; ANTONIW,J; BAKER, S E; BLUHMN, B H; BREAKSPEARL, A; BROWN, D W; BUTCHKO, R A E; CHAPMAN, S; COULSON, R; COUTINHO, P M; DANCHIN, E G J; DIENER, A; GALE, L R; GARDINER, D M; GOFF, S; HAMMOND-KOSACK, K E; HILBURN,K; HUA-VAN, A; JONKERS, W; KAZAN, K; KODIRA, C D; KOEHRSEN, M; KUMAR, L; LEE, Y H; LI, L; MANNERS, J M; MIRANDA-SAAVEDRA, D; MUKHERJEE, M; PARK, G; PARK, J; PARK, S Y S; PROCTOR, R H; REGEV, A; RUIZ-ROLDAN, M C; SAIN, D; SAKTHIKUMAR,S; SYKES, S; SCHWARTZ, D C; TURGEON, B G; WAPINSKI, I; YODER, O; YOUNG, S; ZENG, Q; ZHAOU, S; GALAGAN, J; CUOMOL, C A; KISTLER, K C and REP, M (2010). Comparative genomics reveals mobile pathogenicity chromosomes in Fusarium. Nature, 464: 367-373. DOI:10.1038/ nature08850.

MARCUS, R; FISHMAN, S; TALPAZ, H; SALAMON, R and BAR-JOSEPH, M (1984). On the spatial distribution of citrus tristeza virus disease. Phytoparasitica, 12: 45-52. DOI:10.1007/BF02980797.

MEPSTED, R; NYANDUSA, C; FLOOD, J and COOPER, R M (1991). A non-destructive, quantitative method for the assessment of infection of oil palm by Fusarium oxysporum f. sp. elaeidis. Int. 
J. Oil Palm Res., 3: 329-335. http:/ / www.cabi.org/ isc/ datasheet / 24639

MEPSTED, R., FLOOD, J; PAUL, T and COOPER, R M (1994). Virulence and aggressiveness in Fusarium oxysporum f. sp. elaeidis; implications for screening for disease resistance. Oleagineux, 49: 209-212. http://agris.fao.org/agris-search/search. do?recordID=FR19810608425.

MEUNIER, J ; RENARD, J L and QUILLIC, G (1979). Heredity of resistance to Fusarium wilt in the oil palm Elaeis guineensis Jacq. Oleagineux, 34: 555561. http:/ / agris.fao.org/agris-search/search.do? recordID=FR19810608425

MICHIELSE, CB and REP, M(2009). Pathogen profile update: Fusarium oxysporum. Mol. Plant. Pathol., 10: 311-324. DOI:10.1111/j.1364-3703.2009.00538.x.

MOUYNA, I; RENARD J L and BRYGO, Y (1996). DNA polymorphism among Fusarium oxysporum f. sp. elaeidis populations from oil palm, using a repeated and dispersed sequence 'Palm'. Curr. Genet, 30: 174-180. DOI:10.1007/s002940050117.

MUSOLI, C P; PINARD, F; CHARRIER, A; KANGIRE, A; HOOPE, G $\mathrm{M}$; KABOLE, C; OGWANG, J; BIEYSSE, D and CILAS, C (2008). Spatial and temporal analysis of coffee wilt disease caused by Fusarium xylarioides in Coffea canephora. Eur. J. Plant. Pathol., 122: 451-460. DOI:10.1007/ s10658-008-9310-5.

NEI, M and KUMAR, S (2000). Molecular Evolution and Phylogenetics. Oxford University Press, New York. https://books.google.com.my/ books?isbn $=0199881227$

O'DONNELL, K; KISTLER, H C; CILGENIK, E and PLOETZ, R C (1998). Multiple evolutionary origins of the fungus causing Panama disease of banana: concordant evidence from nuclear and mitochondrial gene genealogies. Proc. Nat. Acad. Sci. USA, 95: 2044-2049. http://www.pnas.org/ content/95/5/2044.full

O'DONNELL, K; SARVER, B A J; BRANDT, M; CHANG, D C; WANG, J N; PARK, B J; SUTTON, D A; BENJAMIN, L; LINDSLEY, M; PADHYE, A; GEISER, D M and WARD, T J (2007). Phylogenetic diversity and microsphere array-based genotyping of human pathogenic Fusaria, including isolates from multistate contact lens-associated US keratitis outbreaks of 2005 and 2006. J. Microbiol., 45: 22352248. DOI:10.1128/JCM.00533-07.
PAPAVIZAS, G (1967). Evaluation of various media and antimicrobial agents for isolation of Fusaria from soil. J. Phytopathol., 57: 848-852. https:/ / www. cabdirect.org/ cabdirect/abstract/19671103688

PRENDERGAST, A G (1957). Observations on the epidemiology of vascular wilt disease of the oil palm (Elaeis guineensis Jacq.). J. West Afr. Inst .Oil Palm Res., 2: 148-175. https: / / www.cabdirect.org/ cabdirect/abstract/19581100178

PYLER, T R; SIMONE, G W; FERNANDEZ, D and KISTLER, H C (2000). Genetic diversity among isolates of Fusarium oxysporum f. sp. canariensis. Plant Pathol., 49: 155-164. DOI: 10.1046/j.13653059.2000.00427.x

REKAH, Y; SHTIENBERG, D and KATAN, J (1999). Spatial distribution and temporal development of Fusarium crown and root rot of tomato and pathogen dissemination in field soil. Phytopathology, 89: 831-839. http://eprints.icrisat.ac.in/2784/1/ Phytopathology_89_9_831-839_1999.pdf

RENARD, J L; DE FRANQUEVILLE, H; DIABATE, $S$ and OUVRIER, M (1993). Study on the impact of vascular wilt on FFB production in oil palm. Oleagineux, 48: 495-504. http://agritrop.cirad. $\mathrm{fr} / 387880 /$

RIPLEY, B D (1979). Tests of randomness for spatial point patterns. J. Royal. Stat. Soc. Ser., B 41: 368-374. DOI : $10.1051 /$ ps / 2012027.

RUSLI, M H; IDRIS, A S and COOPER, R M (2015). Evaluation of Malaysian oil palm progenies for susceptibility, resistance or tolerance to Fusarium oxysporum f. sp. elaeidis and defence-related gene expression in roots. Plant Pathol., 64: 988-995. DOI: $10.1111 /$ ppa.12301.

TAMURA, K; DUDLEY, J; NEI, M and KUMAR, S (2007). MEGA4: Molecular evolutionary genetics analysis (MEGA) software version 4.0. Mol. Biol. Evol., 24: 1596-1599. DOI: $10.1093 / \mathrm{molbev} / \mathrm{msm} 092$.

TURNER, P D (1981). Oil Palm Diseases and Disorders. Oxford University Press, Kuala Lumpur. DOI: 10.1111/j.1744-7348.1968.tb03860.x.

WANG, B; BRUBAKER, C L; TATE, W; WOODS, M J; MATHESON, B A and BURDON, J J (2006). Genetic variation and population structure of Fusarium oxysporum f. sp. vasinfectum. Australas. Plant Pathol., 55: 746-755. DOI: 10.1111/j.1365-3059.2006.01445.x. 